\title{
INTRODUCTION TO THE SYMPOSIUM ON UNDOING DISCRIMINATORY BORDERS
}

\author{
Catherine Briddick* and Cathryn Costello**
}

Migration laws and controls distribute important social goods: the right to enter and reside in a particular state, and the rights that attach to any such residence. Migration controls determine individuals' life chances, including sometimes, their very survival. Migration control is a broad concept. Some practices, such as visa administration, control the possibility of travel by regular means, dictating access to mobility opportunities. Other aspects of migration control, such as the conferral of nationality, determine access to permanent residence rights, and the legal ability to pass on membership of a particular state to one's children. Some forms of migration control are automated and may also be undertaken by private actors, including for-profit companies. Others may involve determination or adjudication by individual officials or judges. What unites this broad set of practices is that they comprise important public functions with profound implications for both "outsiders" and "insiders." As Chandran Kukathas argues, migration controls pose a threat to equality within states, challenging the notion that these practices primarily affect imagined "outsiders."1 Migration controls impact both "without" and "within" the state.

This introductory essay explores discrimination in migration control and discusses how such treatment may be approached from an international legal perspective. We introduce the symposium's contributors and essays and establish the need for further research on this topic.

\section{Exploring Discrimination in Migration Law and Control}

The distribution of migration opportunities globally is deeply unequal, with nationals of some generally wealthy, stable, states benefitting from far greater migration opportunities than those from poorer, or unstable ones. An examination of any individual state's migration controls also often reveals problematic patterns of disadvantage. Contemporary migration controls frequently disadvantage women, racial and religious groups, and those whose sexual orientation, gender-identity or family status departs from the nuclear hetero-norm. To many, it is unsurprising that discrimination is rife in migration laws and controls, given that these practices reflect nationalist, colonial, and postcolonial projects of racialized and gendered exclusion and subordination. And yet, with a few notable exceptions, ${ }^{2}$ the question of the legality of discrimination at borders is underexplored. Not all distributive inequalities in opportunities for migration are open to challenge as unlawful discrimination. Whether these inequalities, within and across states, are legally discriminatory, is the focus of this symposium.

* Departmental Lecturer in Gender and International Human Rights and Refugee Law, Refugee Studies Centre, University of Oxford, United Kingdom. Principal Investigator of the Undoing Discriminatory Borders project, funded by the John Fell Fund, Reference Number 0007824.

** Professor of Fundamental Rights, Hertie School, Berlin, Germany; Professor of Refugee and Migration Law, Refugee Studies Centre, University of Oxford, United Kingdom (on special leave). Principal Investigator on ERC Grant RefMig, Grant Agreement 716968, which supported work on this symposium.

${ }^{1}$ Chandran Kukathas, Immigration and Freedom (2021).

2 See, e.g., Maarten den Heijer, Visas and Non-Discrimination, 20 Eur. J. Migration \& L. 470 (2018); Neil Graffin \& Juan J. Garcia Blesa, Racial Profiling in Immigration Control, 8 INT'L Hum. RTs. L. Rev. 245 (2019).

(C) Catherine Briddick and Cathryn Costello 2021. Published by Cambridge University Press on behalf of The American Society of International Law. This is an Open Access article, distributed under the terms of the Creative Commons Attribution licence (http:// creativecommons.org/licenses/by/4.0/), which permits unrestricted re-use, distribution, and reproduction in any medium, provided 
Migration controls rest on the legal permissibility of states treating "citizens" and "strangers" differently. We take this as a given in this symposium. International law reflects, indeed constitutes, states' rights to engage in this basic differentiation, and control the entry and residence of foreigners. However, this basic assumption does not render migration and nationality zones of unfettered sovereignty, immune from legal or other scrutiny. The key question is not whether, but rather how, international law shapes and constrains state prerogatives in this field. In practice, when allocating rights of entry and residence, states create highly differentiated and stratified status-based hierarchies. When this distribution disadvantages individuals or groups on suspect grounds, such as race or sexual orientation, it is legally and ethically problematic.

\section{The Essays}

This symposium brings together scholars with diverse approaches to this topic, from those who defend states' broad discretion over admissions, to those who argue that non-discrimination norms can and should apply in robust fashion in this domain. Contributions focus on a range of human rights norms, in particular the prohibitions on race and sex discrimination under the Convention on the Elimination of All Forms of Racial Discrimination (CERD) ${ }^{4}$ and the Convention on the Elimination of All Forms of Discrimination against Women (CEDAW). ${ }^{5}$ The symposium authors consider various forms and contexts of discrimination, and explore some of the challenges - normative, doctrinal, and institutional - to identifying and remedying discrimination in migration control.

E. Tendayi Achiume, from UCLA, charts "the contemporary system of racial borders: border regimes that variously allocate and curtail mobility and migration on a racial basis." Her account operates at a high level of generality, arguing, for instance, that the category of "asylum seeker" under European migration regimes is "de facto racialized" as it consists "largely of non-White persons, including nationals of Muslim majority countries." Achiume draws on her report to the General Assembly on digital borders, ${ }^{7}$ to argue that governments and others are developing and deploying emerging technologies against migrants and stateless persons in a racially discriminatory and subordinating fashion. In doing so, Achiume identifies an emerging form of border discrimination. "Digital borders", Achiume contends, "are digital racial borders."8

As Achiume focuses on technologies that appear to be race neutral, her essay is primarily concerned with indirect discrimination. Direct discrimination involves explicitly treating one person less favorably than another based on a protected characteristic. Indirect discrimination involves treating a person less favorably than another through rules or practices which, although based on apparently neutral criteria, in fact disadvantage those who share the protected characteristics. Indirect discrimination is, therefore, an effects-based concept. Achiume's legal arguments rest on a robust application of indirect discrimination norms to border surveillance and control. She charts states' mobilization of facially neutral technologies to exclude admission seekers on racial grounds arguing, among other things, that national origin or other nationality restrictions "can and do operate as proxies for race."

\footnotetext{
${ }^{3}$ For critiques of this position and classification of some communities as citizens/strangers, see E. Tendayi Achiume, Migration as Decolonization, 71 Stan. L. Rev. (2019); Nadine El-Enany, (B) Ordering Britain: Law, Race and Empire (2020).

${ }^{4}$ International Convention on the Elimination of All Forms of Racial Discrimination, Dec. 21, 1965, 660 UNTS 195.

${ }^{5}$ Convention on the Elimination of All Forms of Discrimination Against Women, Dec. 18, 1979, 1249 UNTS 13.

${ }^{6}$ E. Tendayi Achiume, Digital Racial Borders, 115 AJIL Unbound 333 (2021).

${ }^{7}$ Report of the Special Rapporteur E. Tendayi Achiume on Contemporary Forms of Racism, Racial Discrimination, Xenophobia and Related Intolerance, UN Doc. A/75/590 (Nov. 10, 2020).

${ }^{8}$ Emphasis added.
} 
Achiume's arguments rest on two assumptions: that race is a colonial social construct and that indirect discrimination is integral to any concept of discrimination. These assumptions are likely to be shared by most discrimination lawyers, to whom Achiume's legal analysis will appear entirely sound and, indeed, uncontroversial. Cathryn Costello, from the Hertie School, and Michelle Foster, from the University of Melbourne, argue, however, that the ICJ's recent interpretation of CERD's prohibition on race discrimination seems to diverge from these basic premises.'

Costello and Foster focus on the recent admissibility ruling of the ICJ in Qatar v. U.A.E., ${ }^{10}$ critiquing it for its marginalization of the prohibition of race discrimination. They argue that the ICJ "effaces" race discrimination by failing to interpret the ground of race appropriately, by failing to consider that nationality discrimination may be indirect race discrimination, and by treating the categories of "race" and "nationality" as effectively mutually exclusive. In contrast to the ICJ's interpretative approach, Costello and Foster argue for a more contextual understanding of race, and for serious attention to be paid to how nationality discrimination may be indirect race discrimination. Reading the essays by Achiume and Costello and Foster side by side reveals the importance and implications of basic doctrinal analysis in this field. There are, undoubtedly, significant institutional and evidentiary challenges to be surmounted to demonstrate indirect discrimination. However, without a clear, conceptual foundation to inform the interpretation of core human rights treaties, discriminatory practices evade legal scrutiny altogether.

Liav Orgad also focuses on CERD's prohibition of race discrimination. ${ }^{11}$ Orgad identifies a number of shortcomings in the international legal regulation of migration and offers an original framework with which to remedy them. He starts by drawing on jurisprudence from a range of international courts and treaty bodies to argue that international law "largely leaves admission decisions to state discretion." Orgad then identifies three core issues which, in his view, require clarification: the goals, criteria, and means that may be permissibly used to restrict immigration; the extent of states' prerogative to use migration controls to maintain their "distinctive" identities; and, how migration should be regulated globally. Orgad offers a three-step process to clarify these issues, and to evaluate when states' differentiation between migrants may be discriminatory, starting with an evaluation of the policy goal of any immigration preference or restriction, before examining the criteria and means used to implement it.

Anuscheh Farahat, from Friedrich-Alexander-University Erlangen-Nürnberg, focuses on migration control's discriminatory impact inside states. ${ }^{12}$ Her essay explores whether migration controls' differentiation between migrants in terms of their access to work, and rights at work, is unlawfully discriminatory. Farahat draws on multiple sources to demonstrate that international law constrains the extent to which states may limit migrants' right to work, noting that the key issue is that of justification. She argues for a "transformative equality" approach to these issues, drawing on the scholarship of Sandra Fredman. ${ }^{13}$ She also demonstrates that this approach is consonant with the object and purpose of the human rights norms in question, which seek to balance states' migration control prerogatives with the right to equality. In particular, she argues that a transformative equality approach would clarify the standard of justification for differential treatment in the labor market, and states' positive obligations to remove structural exclusion and inequality.

Catherine Briddick, from the University of Oxford, focuses on the gendered disadvantage migration law generates, examining its impact on women at every stage in their physical and legal journeys. ${ }^{14}$ Briddick considers

${ }^{9}$ Cathryn Costello \& Michelle Foster, Race Discrimination Effaced at the ICJ, 115 AJIL UnBound 339 (2021).

${ }^{10}$ Application of the International Convention on the Elimination of All Forms of Racial Discrimination (Qatar v. U.A.E.) Application Instituting Proceedings (ICJ, June 11, 2018).

${ }^{11}$ Liav Orgad, When Is Immigration Selection Discriminatory?, 115 AJIL Unbound 345 (2021).

12 Anuscheh Farahat, Discrimination Inside: Non-Discrimination as Tool of Migrant Integration, 115 AJIL UNBound 350 (2021).

${ }^{13}$ Sandra Fredman, Discrimination Law (2011).

${ }^{14}$ Catherine Briddick, When Does Migration Law Discriminate Against Women?, 115 AJIL Unbound 356 (2021). 
whether migration rules that produce such disadvantage are open to challenge under the international legal regime charged with eradicating it: CEDAW.

In her previous work, Briddick has argued that sex discrimination is a pervasive feature of British immigration law. ${ }^{15}$ Here, Briddick draws on CEDAW Committee General Recommendations to identify and impugn as either directly or indirectly discriminatory, a range of laws and practices regularly used by states to control migration. Briddick argues that in these General Recommendations, the CEDAW Committee interprets the Convention robustly, requiring states to "root out" discrimination in migration control, including, for example, by increasing women's access to safe and regular migration pathways. She argues, however, that when dealing with individual communications, the Committee is far less willing to hold states responsible for violating the discrimination lawbased obligations it has itself identified. Indeed, Briddick's essay reveals a "striking disparity" between the Committee's interpretation of the Convention's rights and protections and its application of these interpretations to states. She concludes by observing that it is "not enough to know which laws and practices discriminate against women. Such discrimination, when challenged, must be remedied."

The symposium's final essay, by Colm O'Cinnéide from University College London, surveys the challenges to discrimination at the border across various human rights bodies, exploring why the "cutting edge" of the right to non-discrimination "becomes blunted at the border." ${ }^{16}$ O'Cinnéide explains that while international human rights law includes numerous prohibitions on discrimination, the assumed legitimacy of migration controls impedes legal challenges, as do statist readings of treaty provisions granting migration control exceptions, and highly deferential judicial approaches to issues of justification.

O'Cinnéide critiques both the UN Human Rights and CERD Committees. He argues that their General Comments and Recommendations affirm non-discriminatory treatment in general terms, while lacking detail on when migration control rules or practices that disadvantage particular groups may, or may not, be justified. O'Cinnéide's reading of the episodic caselaw is also a rather pessimistic one. Yet, in many ways, his essay confirms analyses of the jurisprudence undertaken by other contributors to this symposium. ${ }^{17}$

Overall, O'Cinnéide's essay echoes a general concern expressed by this symposium's authors, that UN Treaty Bodies, in particular, have made general statements supportive of non-discrimination in migration control, but have failed to apply the relevant principles effectively, or at all. In contrast, regional human rights bodies, notably the Inter-American Court and Commission, and the European Court of Human rights have, for example, recognized some forms of indirect race discrimination in migration controls. As Costello and Foster conclude, " $\mathrm{h}]$ uman rights norms take shape in multiple fora, including domestic and regional ones." When it comes to discrimination in migration control, "the global level has fallen short."

The differences across these contributions reflect not only different takes on the limits of state discretion in migration control, but also different conceptions of the principle of non-discrimination. Indeed, one of the key doctrinal questions the symposium prompts is the extent to which there is a settled concept of discrimination in international law which cuts across different human rights instruments. Many contributors assumed so, while others identified the need for a particular normative theory to inform a "better" interpretation of non-discrimination norms in this field. As Farahat and O'Cinnéide note, the Inter-American Court of Human Rights has even described the prohibition of discrimination on certain protected grounds, including migration status, as a jus cogens

\footnotetext{
15 Catherine Briddick, Precarious Workers and Probationary Wives: How Immigration Law Discriminates Against Women, 29(2) SOc. \& LegaL STUD. 201 (2020).

${ }^{16}$ Colm Ó Cinnéide, Why Challenging Discrimination at Borders is Challenging (and Often Futile), 115 AjIL UnBound 362 (2021).

17 See Başak Çalı et al., Hard Protection Through Soft Courts? Non-Refoulement Before the United Nations Treaty Bodies, 21(3) GERMAN LAW Journal 355(2020); Catherine Briddick, Unprincipled and Unrealised: CEDAW and Discrimination Experienced in the Context of Migration Control (forthcoming 2022).
} 
norm. ${ }^{18}$ And yet, even in that legal regime, some discrimination on grounds of nationality and migration status is permitted, as Orgad explores. Scholarship on theories of non-discrimination may help international lawyers to clarify the wrong of discrimination, ${ }^{19}$ but clearly the normative underpinnings of an international legal concept of discrimination need further work.

An Agenda for Future Research

This symposium, which focuses on discrimination on the grounds of race and against women, is, we acknowledge, only a very partial examination of contemporary discriminatory borders. Discrimination on other suspect grounds, including religion, sexual orientation, and disability are all also prevalent in migration control and have, in the main, evaded both scholarly scrutiny and legal challenge. ${ }^{20}$ Migration control is, moreover, a site of intersectional discrimination. Discrimination on multiple grounds, including for example, migration status, nationality, and race, co-constitute and compound each other to entrench existing patterns of disadvantage and subordination, and to create new ones. The need to understand and remedy intersectional discrimination in both domestic and international law is now widely appreciated. ${ }^{21}$ Discrimination on the grounds not covered in this symposium, and intersectional discrimination are, therefore, topics that warrant further and detailed consideration.

Finally, the contributors to this symposium focus, in the main, on key norms and their interpretation by courts and treaty bodies. Yet combatting discrimination in other fields is generally understood as requiring deep institutional and attitudinal change. Litigation and adjudication are necessary to secure such change, but they are unlikely to be sufficient. Indeed, many systems of discrimination law work on the assumption that individual litigation and expost remedies are unlikely to be effective by themselves, and include institutional monitoring and enforcement of equality commitments. If this empirical insight applies when those challenging the discrimination are "insiders," it is even more needed in the field of migration control. Thinking through questions of institutional efficacy are just as urgent as those of doctrinal clarity, and also require exploration. The disadvantage produced by migration law and control may only be redressed, and migration law itself transformed, through concerted and collaborative action that takes place at a number of different sites and at a variety of legal and institutional levels.

\section{Conclusion}

This symposium has identified considerable doctrinal and normative contestation around discriminatory borders. For those who understand discrimination as harmful, in the sense of entailing both stigmatizing practices that undermine human dignity and distributive inequalities, clarifying human rights obligations in this field is an urgent and important task. We hope this symposium makes some contribution to that endeavor. ${ }^{22}$

${ }^{18}$ Juridical Condition and Rights of the Undocumented Migrants, Advisory Opinion OC-18/03, Inter-Am. Ct. H.R. (ser. A) No. 18 (Sept. 17, 2003).

19 See, e.g., Tarunabh Khaitan, A Theory of Discrimination Law (2015).

${ }^{20}$ Notable exceptions include Eithne Luibhéid, Heteronormativity and Immigration Scholarship: A Call for Change, 10 GLQ: J. LESBIAN \& GAY STUD. 227(2004); Ben Saul, Migrating to Australia with Disabilities: Non-Discrimination and the Convention on the Rights of Persons with Disabilities, 16 Australian J. Hum. Rts. 63 (2010).

21 Thanks, in large part, to the work of Shreya Atrey, Shreya Atrey, Intersectional Discrimination (2019).

22 This symposium is part of a wider research project on Undoing Discriminatory Borders, led by Catherine Briddick. We invite potential contributors with further insights into this topic, particularly contributors from the Global South, to contact us to discuss their research and how the project might support it. A special issue of the International Journal of Discrimination and the Law is also in preparation which considers a number of topics covered in this symposium in more detail. 